\title{
On-farm impacts of endophyte technology in the United States
}

\author{
J. A. PARISH ${ }^{1}$ and R. H. WATSON ${ }^{2}$ \\ ${ }^{I}$ Mississippi State University, Department of Animal and Dairy Sciences, Mississippi State, MS, U.S.A. \\ ${ }^{2}$ AgResearch Limited, Lincoln Research Centre, Lincoln, New Zealand
}

JParish@ads.msstate.edu

\begin{abstract}
The on-farm impacts of non-toxic tall fescue endophyte technology have only been partially realised in the United States. Based on current tall fescue acreage, the potential for non-toxic endophyte-infected tall fescue products is immense. However, 6 years after the introduction of the first non-toxic endophyte tall fescue technology to the U.S. market, less than $1 \%$ of the total tall fescue acres in the U.S. have been renovated using this technology. Success with leading producers that influence other producers, educational partnerships, and strong product advertising are factors favouring adoption of this technology. Factors slowing this technology adoption include key markets lacking adequate marketing and technical support, lack of producer awareness and inaccurate perceptions about the technology, and acreage moving out of pasture and into alternative enterprises including urban development. Rapidly changing social, political, and economic conditions have the potential to drive profit-minded producers to give more consideration to forage technology adoption.
\end{abstract}

Keywords: farm level, technology application, technology adoption

\section{Introduction}

The on-farm impacts of non-toxic tall fescue endophyte technology have only been partially realised in the United States to date. Forage-based ruminant livestock production is a significant and integral part of animal agriculture in the southeastern USA. In Mississippi alone, the total value of production of cattle and calves in Mississippi exceeded \$216 million in 2006, ranking sixth among the state's agricultural commodities (USDA 2006). Total cattle inventory in Mississippi on January 1, 2007 was 980000 head including 518000 head of beef cows and 99000 head of beef cow replacements representing approximately 21 000 operations with stocker cattle production also being very prominent (USDA 2007). Ruminant livestock, such as cattle and sheep, are useful in converting vast renewable resources from pasture into food and other products for human consumption. Land that is too poor or erodible for cultivation can become productive when utilised for ruminant grazing. One of the best ways to improve agricultural sustainability is by enhancing the yields and characteristics of forages used in livestock grazing (Oltjen \& Beckett 1996). The value of forages combined with the economic value of grazing livestock rival values for the most important field crops since ruminants obtain 60 to $100 \%$ of their feed nutrients from forages (Allen \& Segarra 2001).

Southeastern USA grasslands are primarily used for beef cowcalf production, while stockering weaned beef calves to feeder weight on high-quality pastures is another important enterprise (Hoveland 2000). There are approximately 24 million hectares of pasture in the southeastern USA, accounting for $75 \%$ of the total USA humid pastureland (Hoveland 1992). Tall fescue (Festuca arundinacea Schreb.) is a cool-season grass grown on over 14 million hectares in this region and is widely used as pasture or hay for livestock (Browning et al. 1998).

According to Thompson et al. (2001), tall fescue is an attractive forage species because of its ability to withstand drought, poor soil conditions, and intensive defoliation from grazing. Stuedemann and Hoveland (1988) report that ease of establishment, wide range of adaptation, long grazing season, tolerance to poor management, and good seed production are desirable agronomic characteristics associated with tall fescue. Despite attributes that make it a desirable forage crop, tall fescue is associated with fescue toxicosis, a condition that alters ruminant livestock grazing behavior (Seman et al. 1999) and adversely affects livestock growth and reproduction (Stuedemann \& Hoveland 1988). Animal toxicity problems are the result of grazing EI (wild-type endophyte-infected) tall fescue (Hill et al. 1994).

The tall fescue endophyte, Neotyphodium coenophialum [Glenn et al. 1996 (formerly Acremonium coenophialum)], is a fungus that resides within the tall fescue plant and imparts positive agronomic qualities to the plant. Surveys in states within the tall fescue region have shown that in excess of $90 \%$ of the tall fescue fields sampled contained high levels of the wild-type endophyte (Lacefield \& Henning 1995). Bacon et al. (1977) were the first to suggest an association between the fungal endophyte and animal toxicity. A 4-year replicated grazing study by Hoveland et al. (1983) provided the convincing proof that poor beef cattle weight gains on tall fescue were related to toxins produced by the fungal endophyte.

Ergot alkaloids produced by $N$. coenophialum have been implicated as causative agents in fescue toxicosis (Hill et al. 1994; Stuedemann et al. 1998). Three classes of ergot alkaloids found in tall fescue are lysergic acid, lysergic acid amides, and ergopeptine alkaloids. Other compounds associated with EI tall fescue are the loline alkaloids and peramine (Siegal et al. 1989; Bush et al. 1990).

Ergovaline, an ergopeptine alkaloid, is generally accepted as the toxic component of EI tall fescue, although no direct evidence supports this hypothesis (Hill et al. 2001). Toxicosis in animals consuming EI tall fescue has been reported to occur at levels of $50 \mathrm{ng}$ of ergovaline/g of grass (Porter 1995). Hill et al. (2001) observed that the ergot alkaloids with the greatest transport potential across isolated ruminant gastric tissues in vitro

Figure 1 Number of all U.S. cattle and beef cow operations, 1991-2006 (USDA 2007).

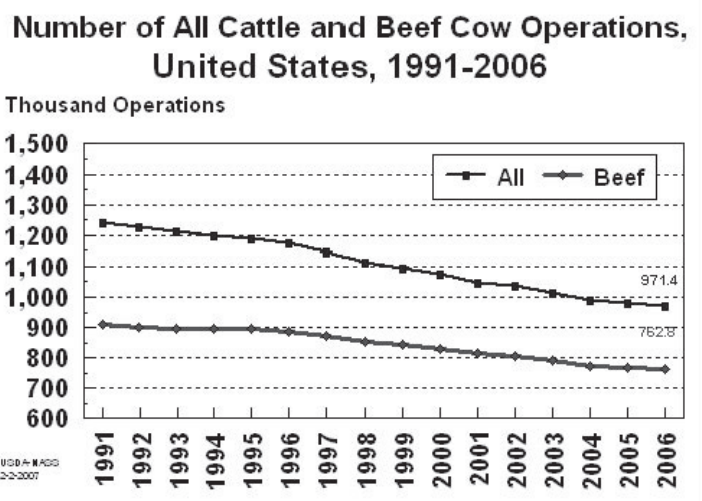


Figure 2 Pasture value by state in 2006 in the U.S. (USDA 2006).

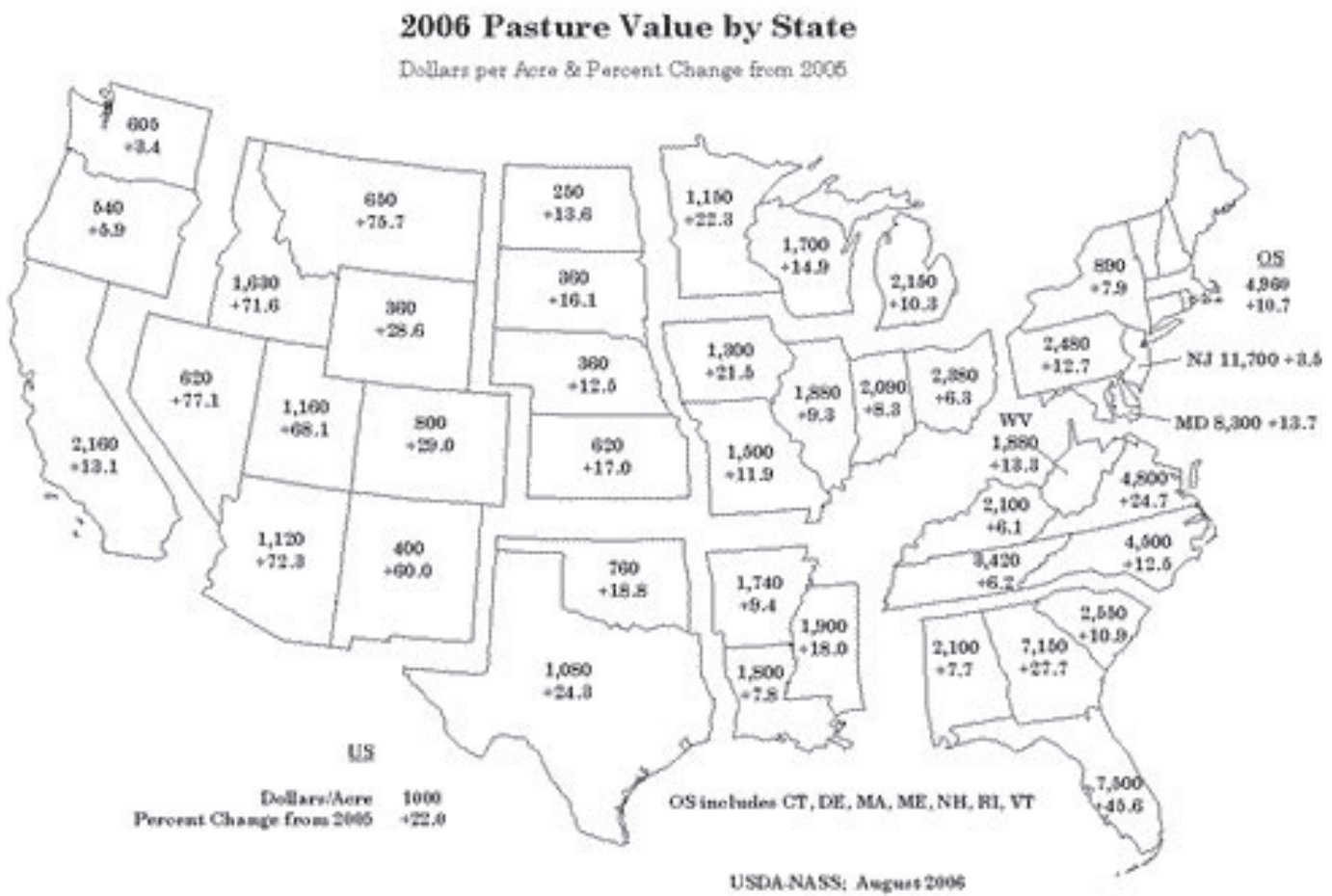

were lysergic acid and lysergol. Ergopeptine alkaloids were also transported across gastric tissues but at a level that was minimal compared to lysergic acid and lysergol, indicating that the latter alkaloids may play an important role in the pathogenesis of fescue toxicosis.

\section{Nil Ergot Alkaloid Endophytes}

Hoveland (2000) lists the discovery of the tall fescue fungal endophyte and its effect on livestock and the grass plant as one of the major achievements in the management and utilisation of southern USA grasslands. The development and use of stress-tolerant tall fescue with "friendly" nil ergot alkaloid producing endophytes is noted as a future area of emphasis in the improvement of these grasslands. Bush and Burrus (1988) indicated that the potential for selectively eliminating livestock toxins in EI tall fescue existed, since reports from New Zealand claimed that the livestock and insect toxins in EI tall fescue were different. Hill et al. (1991) concluded that reducing ergopeptine alkaloids in EI tall fescue plants resulted in little or no loss of competitive fitness of the plant and recommended selection of tall fescue plants containing little or no ergopeptine alkaloids. Reducing ergovaline concentration in EI tall fescue was postulated to improve animal performance (Agee \& Hill 1994).

Selective elimination of livestock toxins came to fruition in the form of nil ergot alkaloid producing endophytes (AR542 and AR502) discovered by AgResearch, New Zealand. To address the fescue toxicosis problem, these endophytes have been used to infect tall fescue varieties grown in the southeastern USA. These tall fescue varieties include Jesup (Bouton et al. 1997), Georgia-5 (Bouton et al. 1993), and Kentucky-31. Initial research findings indicate that the nil ergot alkaloid producing endophytes provide the benefits of enhanced tall fescue plant persistence without producing clinical signs of fescue toxicosis in livestock (Bouton et al. 2000). The utilisation of nil ergot alkaloid producing tall fescue endophytes holds great promise for reducing production losses from fescue toxicosis and enhancing forage-based livestock production. Hoveland (1993) expressed the opinion that "modification of the fungal endophyte to remove the harmful properties and maintain those beneficial to the host plant is the ultimate solution" to the fescue toxicosis problem.

\section{Adoption of New Endophyte Technologies in Tall Fescue in the U.S.}

Figure 3 U.S. farm production expenditures by farm type, 1996 to 2005 (USDA 2006).

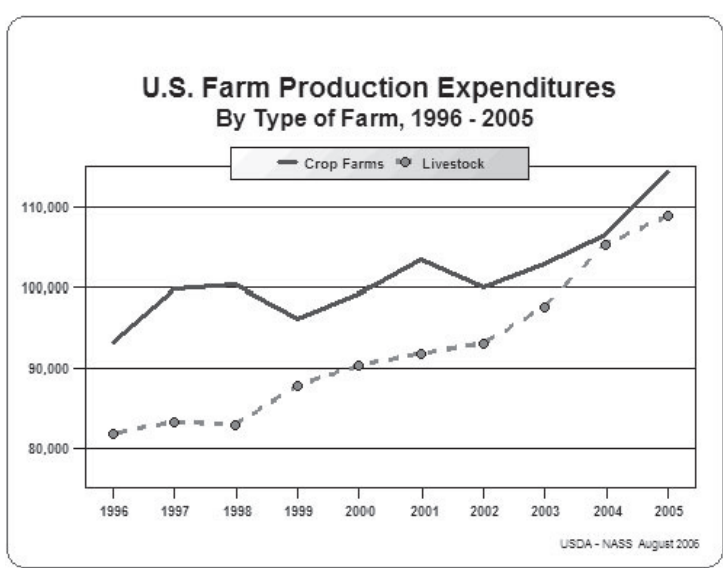


Figure 4 U.S. feed purchase expenses as percent of total farm production expenses in 2002 (USDA 2002).

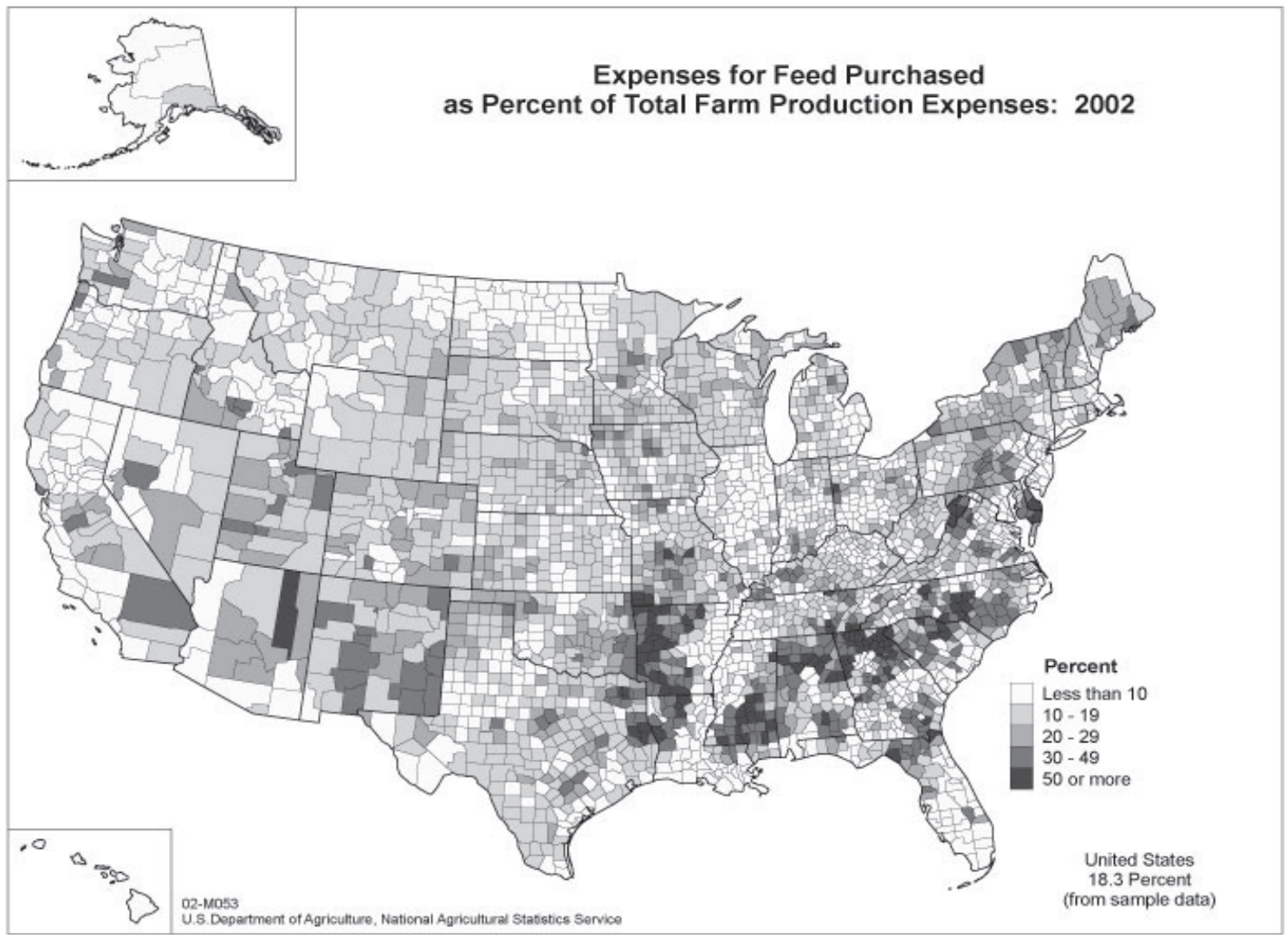

\section{Current status}

Pennington Seed, Inc. (Madison, GA) is the commercial marketer for MaxQ ${ }^{\mathrm{TM}}$ tall fescue, Jesup and GA-5 tall fescue infected with the AR542 nil ergot alkaloid producing endophyte. According to company estimates, 121000 hectares of MaxQ ${ }^{\mathrm{TM}}$ tall fescue have been planted in the United States since commercial sales first began in 2000 (Agee 2006). MaxQ ${ }^{\mathrm{TM}}$ tall fescue planting is reported in at least 35 of the 50 states in the U.S. Approximately $70 \%$ of MaxQ ${ }^{\mathrm{TM}}$ tall fescue establishment has occurred in the last 3 years. In the initial years of $\mathrm{MaxQ}^{\mathrm{TM}}$ tall fescue marketing, Pennington Seed set up 155 on-farm demonstrations in 26 states. A leading Pennington Seed representative stressed that these demonstration sites went a long way towards educating agricultural producers and local Extension personnel about the $\mathrm{MaxQ}^{\mathrm{TM}}$ tall fescue product and its inherent technology. Additionally, numerous research trials in multiple states utilised $\mathrm{MaxQ}^{\mathrm{TM}}$ tall fescue as a forage treatment.

\section{Current demographics impacting tall fescue endophyte technology adoption}

Several trends in livestock production and acreage usage in the U.S. are potentially impacting tall fescue endophyte technology adoption. The number of beef cattle operations is steadily declining (Fig. 1) in favour of larger operational units. Many of the current livestock producers are approaching or have long since passed traditional retirement age. Pasture lease rates and land values are on the rise (Fig. 2) with competition from urban development in many areas.
Farm production expenditures are increasing (Fig. 3) with feed purchases accounting for a very large proportion of these expenditures on livestock operations (Fig. 4). According to Twig Marston, Ph.D., Kansas State University, "Nutrition has long been singled out as the largest expense for cow-calf producers. Feed costs typically represent $65 \%$ to $72 \%$ of the annual cow budget. Balancing favorable cowherd performance with low nutritional costs could be the greatest challenge this segment of the industry faces" (Field 2006). A survey of more than 200 industry specialist and producers identifying management priorities in the commercial cow-calf business in the U.S. ranked pasture and range management as the second priority out of 15 management categories with harvested forages and supplemental feeds ranking tenth in the same survey. Respondents emphasised grazing as the preferred route for providing adequate nutrition to the cowherd. In the current political climate of tax credits for ethanol production from corn driving demand for corn, feed inputs in livestock production are becoming increasingly expensive relative to forage alternatives. There are several potential implications for livestock production of "high corn prices" in the short-term including depressed cattle prices for all classes of cattle, elevated feedlot cost of gain, market signals driving placement of heavy-weight cattle instead of calf feds, and profit-minded producers seeking lower cost of gains available on forage-based systems.

As the cost of purchased commodity by-product and co-product feeds rises relative to the cost of forage alternatives, livestock production systems effectively utilising forage technologies are 
poised to be highly competitive. Stocker operations will likely be an attractive alternative to add weight to calves on forage systems prior to finishing in the next few years. Additionally, growing environmental and animal welfare considerations in the U.S. could contribute to shifting more focus towards forage-based livestock production systems. The collective sum of these social, political, and economic conditions has the potential to drive profit-minded livestock producers to give more consideration to the adoption of forage technologies.

\section{Potential for tall fescue endophyte technology adoption in the U.S.}

Based on the tall fescue acreage that currently exists in the U.S., the potential for non-toxic endophyte-infected tall fescue products is immense, particularly given that most of the existing tall fescue is infected with the toxic wild-type endophyte. Furthermore, the clear negative impacts of fescue toxicosis on the grazing livestock industries (losses to the beef cattle industry alone are estimated to be around $\$ 1$ billion U.S.), and significant advantages in animal production gained from using the novel endophyte technology, would appear to provide strong motivating factors in the uptake of this technology. However, 6 years after the introduction of the first novel endophyte tall fescue to the U.S. market, less than $1 \%$ of the total tall fescue acres in the Southeast U.S. have been renovated using this product. It is fair to say that this seemingly slow uptake could be somewhat governed by seed supply shortfalls as production capacity is scaled up, and the fact that marketing and Extension campaigns often need time to make an impact. However, it is also fair to say that the early impact is ultimately being determined by what appears to be a relatively slow adoption rate, at least when compared to other proprietary forage seed markets (e.g., New Zealand that has a 5$10 \%$ p.a. pasture renovation rate and proprietary products have a $90 \%$ market share). So what are the factors that are affecting the uptake of this technology on the farm?

\section{Factors favouring tall fescue non-toxic endophyte acreage expansion}

The cornerstone element favouring the expansion of non-toxic endophyte tall fescue product adoption is that the technology is sound and due diligence was done in regard to independent agronomic and animal safety/productivity testing. Around this, a solid marketing and technology transfer campaign could be put forward that greatly improved consumer confidence around this product. A multi-regional approach to product testing ensured that the market area was clearly defined and provided additional confidence for the consumer with the knowledge that the technology worked in their area. The use of extensive independent University testing also allowed the cooperative extension service and researchers in different states to provide their producers with information and relevant technical help with the confidence that they were promoting a proven technology. In fact, the highest rates of adoption have been in states where the Extension service actively encourages the use of non-toxic endophyte-infected tall fescue and provides technical support needed to ensure its success.

Another key to the success of non-toxic endophyte-infected tall fescue lies in understanding the conservative approach taken by many farmers towards new technologies, which in many cases requires that some evidence of success in the "real world" be provided before they will invest themselves. In order to overcome this inherent apprehension by producers, promoters of the MaxQ ${ }^{\mathrm{TM}}$ tall fescue product focused their initial attention on key farmers within the marketing region. These key producers are usually professional farmers (receive their primary income from the farm), innovative and more likely to adopt new technologies at an early stage, and either poses, or are prepared to, change management practices to accommodate the new technology. Donation of seed to these key producers, and providing the necessary technical support through the state Extension service and seed company representatives, resulted in over 150 "demonstration" sites in 26 states within the marketing region. These sites could then be used as real world examples for the success of the novel endophyte product, with the intent that the more skeptical and cautious members of the farming community would proceed with more confidence. It is possibly too early to gauge the success of this "technology trickle down effect"; however, the phenomenon of technology transfer within the farming community is well documented (Waugh 1981), and perhaps one of the more successful means of promoting new technologies.

In the future, economic pressures may become a significant driver of technology adoption in forage-based agriculture. The costs of inputs in agricultural production, including those used in forage-based systems, have risen at a greater rate then the commodities being produced. Ultimately, this erosion of farm profitability must be addressed by improving production efficiencies through the adoption of new technologies. The initial, and probably greatest, improvements in efficiency will need to come in the form of changes in management practices. The climate in the southeast U.S. with its mild winters and high precipitation levels, in combination with well-adapted perennial forage grass and legume species, means that annual dry matter yields in excess of $10000 \mathrm{~kg} / \mathrm{ha}$ can be easily achieved with moderate fertiliser inputs. However, the widespread use of continuous grazing indicates that this forage production is currently underutilised. Under continuous grazing, the average Southeastern cow-calf operation uses between 1 and 2 ha to winter one cow-calf unit. If it is assumed that the cow-calf unit has a total annual forage requirement of between 4000 and 5000 $\mathrm{kg} \mathrm{DM}$ (depending on body weight), then forage utilisation is somewhere between $20 \%$ and $50 \%$ when realising a $10,000 \mathrm{~kg}$ $\mathrm{DM} /$ ha annual forage production level. This low forage utilisation rate generally diminishes, or even completely eliminates, the return on any new forage technology. If, in response to a more competitive economic environment, improvements in grazing management are made that can significantly improve forage utilisation, then the adoption of technologies, such as non-toxic endophyte-infected tall fescue, will result in a greater return from the investment. This scenario will then ultimately become more attractive to a greater number of livestock producers keen on improving profitability.

\section{Factors slowing tall fescue non-toxic endophyte acreage expansion}

The factors slowing the expansion of non-toxic endophyteinfected tall fescue acreage in the U.S. are similar to many new technologies in the agricultural sector. Brady (1981) listed six of the most common reasons given for the lack of technology adoption for farmers with limited resources in developing countries; these were 1) farmers are backward and resist change; 2) Extension services are ineffective; 3 ) inputs are not available or unreliable; 4) ratios of inputs to crop prices discourage adoption; 5) lack of availability of credit; and 6) technology is not applicable to actual farmers' conditions. It is perhaps difficult to see how these factors in developing countries might be relevant 
to the adoption of a technology in the U.S., the wealthiest nation in the world. However, a closer look suggests that at least some of these issues are the applicable to the present topic.

It is an overstated and largely inaccurate stereotype to suggest that farmers are backward and resistant to change. While it is true to say that many in the agricultural community are conservative in their approach to new technology, most livestock producers will try something if they can see the clear benefit for their production system and its adoption does not conflict with their personal life goals. If this is the case, then why is a more rapid adoption not observed for a technology like non-toxic tall fescue endophytes that have been shown without exception, to have significant benefits over the previously commercially available tall fescue cultivars?

The answer to this, in part, may have to do with the physical resource of the farm. Considering that the average beef cattle farmer in the Southeast U.S. has a herd size somewhere between 20 and 40 cows and that their primary source of income is off the farm, it is perhaps easier to understand why more farmers are not investing in new forage technologies. These "part-time" farmers are often engaged in agriculture primarily for the lifestyle rewards and are less focused on a profitable farming system in many cases. These individuals are generally unwilling to encumber themselves with additional time requirements that may be needed to manage a new technology and opt to compensate for a lower management input by running a more extensive farming system with more forage production capacity (hectares or acres) than the cattle require. In this situation, producers can rationalise that it is hard to justify investing money in a forage technology when the chance of realising a return on that investment is minimal. Interestingly though, it can be argued that the producer's level of management is a greater determinant of the technology adoption decision, rather than size of operation. Long-term, the average size of operations with high management levels may change as economics dictate or the nature of the operation may shift to more focused or niche production and/ or marketing efforts.

It was mentioned in the previous section that the highest rates of adoption have been in states where the Extension service actively encourages the use of non-toxic endophyte-infected tall fescue and provides technical support needed to ensure its success. The converse of this is true. Producer experiences with consulting Extension personnel concerning non-toxic endophyte-infected tall fescue technology that result in inaccurate or insufficient information transfer can either turn a producer off from considering the technology or harm the confidence level that the producer places in Extension if it is suspected that "bad advice" was provided. To avoid these scenarios, training of Extension personnel at the county, area, and even state levels on nontoxic endophyte technologies is prudent. The effectiveness of Extension services is challenged nationwide with an attrition of Extension positions and personnel with agricultural backgrounds. Enhanced coordination amongst Extension personnel, University researchers, and industry is needed for effective technology transfer and associated development of resource materials for use by Extension personnel that assists them in providing researchbased, up-to-date, and reliable information.

The point made earlier about lack of technology adoption being associated with the technology not being applicable to farmers' conditions raises a research challenge. If tall fescue cultivars infected with non-toxic endophytes were developed and proven to be a viable forage crop alternative for areas outside the traditional U.S. tall fescue belt, then the potential market for and on-farm impact of tall fescue non-toxic endophyte technology would be greatly expanded. For example, the Gulf Coast region of the Southeastern U.S. is directly south of the current tall fescue growing region. Many producers in the northern regions of these states have acreage of non-toxic endophyte-infected tall fescue in production. Producers in the Gulf Coast region have the opportunity to attend field days and statewide Extension and industry programmes that discuss the use of non-toxic endophyte-infected tall fescue in other areas of their states. In addition, these producers have the advantage that wild-type toxic tall fescue eradication would not be a large issue on their farms if an adapted non-toxic endophyte-infected tall fescue alternative was introduced to their region. The Gulf Coast region producers often have very limited cool-season perennial forage options and currently rely heavily on cool-season annuals and hay and supplement feeding as the winter nutritional programmes for their livestock. A tremendous opportunity for non-toxic endophyte technology expansion lies in this region if the issue of forage adaptability and persistence can be successfully addressed.

Others factors that serve to inhibit adoption of non-toxic endophyte-infected tall fescue include: 1) key markets lacking adequate marketing and technical support; 2) lack of producer awareness as to the technology (may think endophyte-free); 3) negative experiences with endophyte-free tall fescue persistence; 4) perceptions that tall fescue is not adapted to a particular area; 5) lack of "buy-in" from local Extension or University research personnel; and 6) acreage moving out of pasture and into alternative enterprises including urban development

\section{Summary and Implications}

While incorporation of non-toxic endophyte-infected tall fescue into forage-based livestock production systems in the U.S. has not proceeded at a rapid pace in the initial years of commercial availability, many influencing factors are currently changing to favour the adoption of this technology in the coming years. A leading beef cattle production textbook used in many University beef cattle science courses in the U.S. includes a discussion of forces driving concentration and integration of the U.S. beef industry (Field 2007). It lists consumer demand, public policy, survival of the fittest in an environment of increasing competition, and the loss of producers who choose to retire rather than adapt. Consumer demand, public policy, and survival of the fittest in an environment of increasing competition are factors that will likely push profit-oriented livestock producers to give serious consideration to adopting non-toxic endophyteinfected tall fescue in the future. The loss of producers from livestock production who choose to retire rather than adapt, while potentially impacting on individual agricultural families and rural communities, is a likely long-term trend for producers who choose to forego adoption of technologies such as non-toxic endophyte-infected tall fescue.

\section{REFERENCES}

Agee, C.S.; Hill, N.S. 1994. Ergovaline variability in Acremonium-infected tall fescue due to environment and plant genotype. Crop Science 34: 221-226.

Allen, V.G.; Segarra, E. 2001. Anti-quality components in forage: Overview, significance, and economic impact. Journal of Range Management 54: 409-412.

Bacon, C.W., Porter, J. K.; Robbins, J.D.; Luttrell E.S. 1977. Epichloe typhina from toxic tall fescue grasses. Applied and Environmental Microbiology 34: 576-581.

Bouton, J. H.; Duncan, R.R.; Gates, R.N.; Hoveland, C.S.; Wood, 
D.T. 1997. Registration of 'Jesup' tall fescue. Crop Science 37: 1011-1012.

Bouton, J.H.; Gates, R.N.; Hill, G.M.; Owsley, M.; Wood D.T. 1993. Registration of 'Georgia 5' tall fescue. Crop Science 33: 1405 .

Bouton, J.H.; Hill, N.S.; Hoveland, C.S.; McCann, M.A.; Thompson, F.N.; Hawkins, L.L.; Latch, G.C.M. 2000. Performance of tall fescue cultivars infected with non-toxic endophytes. Pp. 179-185 In: The Grassland Conference 2000. Proceedings of the $4^{\text {th }}$ International Neotyphodium/Grass Interactions Symposium. Eds. Paul, V.H.; Dapprich, P.D. Soest, Germany.

Brady, N.C. 1981. Significance of developing and transferring technology to farmers with limited resources. pp 1-22. In: Transferring Technology for Small-Scale Farming, American Society of Agronomy Special Publication Number 41. Ed. N.R. Usherwood.

Browning, R.Jr., Schrick, F.N. Thompson, F.N.; Wakefield, T.Jr. 1998. Reproductive hormonal responses to ergotamine and ergonovine in cows during the luteal phase of the estrous cycle. Journal of Animal Science 76: 1448-1454.

Bush, L.P.; Burrus, P.B.Jr. 1988. Tall fescue forage quality and agronomic performance as affected by the endophyte. Journal of Production Agriculture 1: 55-60.

Bush, L.P.; Fannin, F. F.; Siegal, M.R.; Dahlman, D.L. 1990. Chemistry of compounds associated with endophyte-grass interactions: saturated pyrrolizidine alkaloids. p. 29 In: Proceedings of the International Symposium on Acremonium/ Grass Interactions. Eds. Quisenberry, S.C.; Joost, R.E. New Orleans, LA.

Field, T.G. 2007. Beef Production and Management Decisions. $5^{\text {th }}$ ed. Pearson Prentise Hall. Upper Saddle River, NJ.

Field, T.G. 2006. Priorities First. Identifying Management Priorities in the Commercial Cow-Calf Business. American Angus Association. St. Joseph, MO.

Glenn, A.E.; Bacon, C.W.; Price, R.; Hanlin, R.T. 1996. Molecular phylogeny of Acremonium and its taxonomic implications. Mycologia 88: 369-383.

Hill, N.S.; Belesky, D. P.; Stringer, W.C. 1991. Competitiveness of tall fescue as influenced by Acremonium coenophialum. Crop Science 31: 185-190.

Hill, N.S.; Thompson, F.N.; Dawe, D.L.; Stuedemann, J.A. 1994. Antibody binding of circulating ergot alkaloids in cattle grazing tall fescue. American Journal of Veterinary Research 55: 419-424.

Hill, N.S., Thompson, F.N.; Stuedemann, J.A.; Rottinghaus, G.W.; Ju, H.J.; Dawe, D.L.; Hiatt III, E.E. 2001. Ergot alkaloid transport across ruminant gastric tissues. Journal of Animal Science 79: 542-549.

Hoveland, C.S. 1992. Grazing systems for humid regions. Journal of Production Agriculture 5: 23-27.
Hoveland, C.S. 1993. Importance and economic significance of the Acremonium endophytes to performance of animals and grass plant. Agriculture, Ecosystems and Environment 44: 3-12.

Hoveland, C.S. 2000. Achievements in management and utilization of southern grasslands. Journal of Range Management 53: 17-22.

Hoveland, C.S.; Schmidt, S.P.; King, C.C.Jr.; Odom, J.W.; Clark, E.M.; McGuire, J.A.; Smith, L.A.; Grimes, H.W.; Holliman, J. L. 1983. Steer performance and association of Acremonium coenophialum fungal endophyte on tall fescue pasture. Agronomy Journal 75: 821-824.

Lacefield, G.D.; Henning, J. 1995. Alternatives for fungus infected tall fescue. AGR-119. University of Kentucky, Lexington, KY.

Oltjen, J.W.; Beckett, J.L. 1996. Role of ruminant livestock in sustainable agricultural systems. Journal of Animal Science 74: 1406-1409.

Porter, J.K. 1995. Analysis of endophyte toxins: fescue and other grasses toxic to livestock Journal of Animal Science 73: 871-880.

Seman, D.H.; Stuedemann, J.A.; Hill, N.S. 1999. Behavior of steers grazing monocultures and binary mixtures of tall fescue. Journal of Animal Science 77: 1402-1411.

Siegal, M.R.; Bush, L.B.; Fannin, N.N.; Latch; G.C.M.; Rowan, D.D.; Tapper, B.A. 1989. Occurrence and insecticidal activity of alkaloids in endophyte-infected plants. p 49 In: Proceedings of a Tall Fescue Toxicosis Workshop. Southern Region Information Exchange Group, Atlanta, GA.

Stuedemann, J.A.; Hill, N.S.; Thompson, F.N.; Fayrer-Hosken, R.A.; Hay, W.P.; Dawe, D.L.; Seman, D.H.; Martin, S.A. 1998. Urinary and biliary excretion of ergot alkaloids from steers that grazed endophyte-infected tall fescue. Journal of Animal Science 76: 2146-2154.

Stuedemann, J.A.; Hoveland, C.S. 1988. Fescue endophyte: History and impact on animal agriculture. Journal of Production Agriculture 1: 39-44.

Thompson, F.N.; Stuedemann, J.A.; Hill, N.S. 2001. Anti-quality factors associated with alkaloids in eastern temperate pasture. Journal of Range Management 54: 474-489.

U.S. Department of Agriculture. 2007. National Agricultural Statistics Service. February 2007. Washington, D.C.

U.S. Department of Agriculture. 2006. National Agricultural Statistics Service. August 2006. Washington, D.C.

U.S. Department of Agriculture. 2002. National Agricultural Statistics Service. 2002 U.S. Census of Agriculture. Washington, D.C.

Waugh, R.K. 1981. Research and promotion of technology use. pp. 67-88 In: Transferring Technology for Small-Scale Farming. American Society of Agronomy Special Publication Number 41. Ed. N.R. Usherwood. 